\title{
RESTORATIVE JUSTICE AT THE MIYO WAHKOTOWIN COMMUNITY EDUCATION AUTHORITY
}

\author{
MATTHEW WILDCAT ${ }^{*}$
}

This article examines the development of restorative justice techniques at the Miyo Wahkotowin Community Education Authority, which operates three schools for the Emineskin Cree Nation in Maskwacis (Hobbema, Alberta). The article begins with an examination of conflict with Maskwacis. Contextualizing the conflict that takes place within the community is necessary to understand the restorative justice techniques employed by Miyo Wahkotowin. While many techniques of restorative justice had previously been implicitly practiced in the schools overseen by Miyo Wahkotowin, officially adopting restorative justice techniques provided a set of ideas that allows Miyo Wahkotowin to explicitly discuss and practice alternate forms of conflict resolution. The article ends by looking at how the use of restorative justice techniques by Miyo Wahkotowin holds transformative potential for the community of Maskwacis as a whole.
Cet article examine le développement de techniques de justice réparatrice à l'autorité scolaire de la communauté Miyo Wahkotowin, qui exploite trois écoles pour la nation crie à Maskwacis (Hobbema, en Alberta). L'article commence par examiner le conflit pour les Maskwacis. Il est en effet nécessaire de mettre le conflit en contexte au sein de la communauté pour comprendre les techniques de justice réparatrice utilisées par les Miyo Wahkotowin. Beaucoup de techniques de justice réparatrice avaient déjà été utilisées implicitement dans les écoles gérées par les Miyo Wahkotowin, mais les techniques officielles en la matière ont fourni des idées permettant aux Miyo Wahkotowin de parler ouvertement d'autres formes de résolution de conflits et de les mettre en pratique. $L$ 'article se termine en examinant de quelle manière l'utilisation de ces techniques par les Miyo Wahkotowin peut donner un pouvoir de transformation à la communauté dans son ensemble.

\section{TABLE OF CONTENTS}

I. INTRODUCTION . . . . . . . . . . . . . . . . . . . . . . . 920

II. UNDERSTANDING THE COMMUNITY OF MASKWACIS . . . . . . . . . . . . . 921

A. Violence ANd CONFlict $\ldots \ldots \ldots \ldots \ldots \ldots \ldots \ldots \ldots \ldots \ldots$

B. Political LANDSCAPE $\ldots \ldots \ldots \ldots \ldots \ldots \ldots \ldots \ldots \ldots \ldots \ldots$

III. RESTORATIVE JUSTICE AT THE MiYO WAHKOTOWIN

COMMUNITY EDUCATION AUTHORITY . . . . . . . . . . . . . . . . . . . . . . 927

A. Programming and Support Services at the

MIYO WAHKOTOWIN COMMUNITY EDUCATION AUTHORITY . . . . 928

B. INTERVENTION HEARINGS AND MEDIATIONS . . . . . . . . . . . . . . . 929

C. Theme One: Restorative Justice As Being

RELATIONSHIP-DRIVEN .................... 930

D. Theme Two: Restorative Justice As A

LANGUAGE TO THINK ABOUt Discipline . . . . . . . . . . . . 931

E. Theme Three: Restorative Justice

AS A CULTURE . . . . . . . . . . . . . . . . . . . . . . . . . . . . . . 932

F. TALKING TO A StUdENT $\ldots \ldots \ldots \ldots \ldots \ldots \ldots \ldots \ldots \ldots . \ldots . \ldots . \ldots 934$

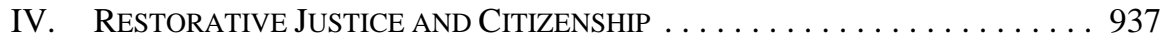

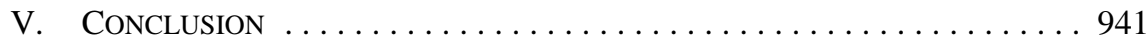

B.A. (Hons.), Native Studies (Alberta); M.A., Indigenous Governance (Victoria). Matthew grew up in the community of Maskwacis (Hobbema, Alberta) and has worked in the community for the past three years. He is also a band member of the Ermineskin Cree Nation. He plans to pursue studies at the Ph.D. level in the fall of 2011 and intends to continue researching pre-reserve Plains Indigenous political collectives, the current state of Indigenous political collectivities, and use his imagination to envision how Indigenous political collectivities might look in the future. 


\section{INTRODUCTION}

What you're doing is building citizens by giving students a diverse tool set for dealing with conflict.

— Dr. Val Napoleon

The above quotation was spoken by Val Napoleon in a meeting I attended with her, Antonio Pena Jumpa, and three staff members of the Miyo Wahkotowin Community Education Authority (Miyo Wahkotowin), which operates three schools for the Ermineskin Cree Nation in the community of Maskwacis, more commonly know as Hobbema, Alberta. The staff members in attendance included the vice principal of the Ermineskin Junior/Senior High School, Sharon Seright; the principal of the Ehpewapahk Alternate School, Wendy Solland; and the Miyo Wahkotowin Director of Student Services, Sanila Mehal. Pena Jumpa, an Indigenous legal scholar from Peru, was in Canada to attend a conference. I was helping to show Pena Jumpa around Maskwacis, where I grew up and maintain close contact, for the afternoon.

My father, Brian Wildcat, is the Executive Director of Miyo Wahkotowin. He explained that some Miyo Wahkotowin staff and board members were planning to attend a restorative justice conference in Edmonton, for which Napoleon was the keynote speaker. Wildcat explained some of the ways that they were incorporating restorative justice into their programming at the school. The presence of Napoleon and Pena Jumpa seemed like a great opportunity for everyone to share their experiences and insights about restorative justice.

In the meeting, the Miyo Wahkotowin staff shared a number of stories that aligned with restorative justice, even though they had only recently started their restorative justice initiative. Seright, who grew up in Maskwacis, talked about how when she speaks with students, she will often remind them that she knows their family and that their behaviour is not in line with their family's values. Mehal gave an example of how a student's attitude changed during a disciplinary hearing where the student's Mosom (grandfather) represented the family instead. Mehal mimed the new posture and facial expression of the student that indicated respect and reverence, but also the startled "I'd better behave” attitude the student had adopted.

Solland also relayed a heartfelt story of how one of her students had broken into the Ehpewapahk Alternate School and stolen a gaming system. A video camera had caught the incident. A police officer brought the student to the school the next day to see if the school wanted to press charges. The student had already sold the gaming system, so there was no chance of recovery. Solland responded that she did not want to press charges. She only wanted to have the student make up for the damages. Not only was the student shocked, but the police officer was as well. To repay for the gaming system, the student helped with work that was needed at Ehpewapahk. Since then, the student has consistently attended class. For an organization that had just started their work on restorative justice, it appeared as if Miyo Wahkotowin was already practising some of the principles of restorative justice.

A few weeks later, Napoleon approached me to write this article on the restorative justice work being done at Miyo Wahkotowin. In Part II of the article, the environment that Miyo 
Wahkotowin operates in is contextualized through a discussion of violence/conflict and the political landscape of Maskwacis. Part III explores restorative justice at Miyo Wahkotowin. The focus here will be placed on the Ermineskin Junior/Senior High School and the Ehpewapahk Alternate School. This Part will examine how Miyo Wahkotowin conceptualizes the principles and practice of restorative justice in the operation of their schools. In Part IV, the focus is on how the conception of citizenship being developed at Miyo Wahkotowin through their restorative justice initiative holds transformative potential for the community.

\section{UNDERSTANDING THE COMMUNITY OF MASKWACIS}

The Ermineskin Cree Nation is located approximately $90 \mathrm{~km}$ south of Edmonton, Alberta, and is one of four Cree bands that comprise the community of Maskwacis. The other bands are the Samson, Louis Bull, and Montana Cree Nations. As of November 2010, the four bands collectively have 14,263 registered members. That breaks down into 72 percent onreserve, 21 percent off-reserve, and 7 percent who live on other reserves. ${ }^{1}$ Maskwacis is one of the largest Indigenous communities in Canada. Each band has their own band-controlled school. The Ermineskin operates Miyo Wahkotowin, which oversees both a K-12 and an alternate program. The Samson Band runs the Nipisihkopahk Education Authority (Nipisihkopahk), which also runs from K-12 with an alternate program. The Louis Bull Band has a full K-9 program and runs a cyber high school. The Montana Band runs a K-6 program.

\section{A. ViolenCE AND CONFLict}

Much has been written about the poor social indicators of reserve communities in Canada. The community of Maskwacis is no different. Like all other First Nations communities, Maskwacis exists within a history of colonialism and a vastly unequal set of power relations with the dominant Canadian society. These power relations are aided and abetted by the pervasive racism in Canadian society; ${ }^{2}$ the denial of white privilege; ${ }^{3}$ an obfuscation of history; ${ }^{4}$ and, ultimately, the general will of European-Canadian settlers to maintain their

The population profile of each Canadian First Nation can be viewed online: Indian and Northern Affairs Canada <http://pse5-esd5.ainc-inac.gc.ca/fnp/Main/index.aspx?lang=eng > . See Appendix A for a full profile of the Maskwacis Bands. The data is current to February 2011 and is based on registered population.

2 One example is the continuing abuse of Indigenous peoples at the hands of the police, which has repeatedly resulted in the death of Indigenous peoples, and a lack of punitive measures against offending officers. For recent example of police violence against a Maskwacis resident, see Conal Pierse, "House arrest for Wetaskawin RCMP officer: Pleaded guilty in prisoner assault” Edmonton Journal (26 November 2010), online: Edmonton Journal <http://www.edmontonjournal.com/House+arrest + Wetaskiwin+RCMP+officer/3885780/story.html $>$.

3 Note the recent mini-controversy in Edmonton around the language of white privilege on the Racism Free Edmonton website. The language of white privilege was quickly taken down after white mobilization on the issue. Even liberal-leaning columnist Paula Simons gives a roundabout argument neutralizing the concept of white privilege: Paula Simons, "Anti-racism website bizarre, offensive to 'real' Edmontonians: Obsession with ‘white privilege' patronizing, exclusionary” Edmonton Journal (9 November 2010), online: Edmonton Journal <http://www.edmontonjournal.com/life/Anti+racism+ website+bizarre+offensive+real+Edmontonians/3798744/story.html $>$. The short article talking about white privilege that was previously referenced on the Racism Free Edmonton website can be viewed in print: Peggy McIntosh, “White Privilege: Unpacking the Invisible Knapsack” (1990) 49:2 Independent School 37.

4 Note the numerous comments on any internet news article pertaining to Indigenous rights and title, which align with the general idea that Indians should be stripped of all rights and assimilated into the body politic as articulated in the Statement of the Government of Canada on Indian Policy, 1969 (The White Paper): Indian Affairs and Northern Development, Statement of the Government of Canada on 
position of dominance on Indigenous lands. ${ }^{5}$ While extreme, the following statement, left on a CBC news article comment board before being removed by a moderator, illustrates the continuing racism built into Canadian society:

Imagine that you have no understanding of the issue. Imagine that we are way more civilized than the savages that live on the land — not OWN it. Imagine you live in squalor on a dirt floor with no water or hygiene. Imagine you eat very little beacause the "Men”' eat first and most. Imagine being raped by your dirty uncle Clarence and his Brothers (including your dad ) then imagine that you can not read write or spell and the alternative is to learn to read write and spell but you may have to "give it up" to a priest or two in exchange for some learning, food and adequate shelter. Where are you better off? ${ }^{6}$

In recent years the public has been exposed to an outward face of violence within Maskwacis due to a significant amount of gang activity, which has received a large amount of media coverage. This outward face of violence has seen a number of gang-related deaths in recent years and the establishment of a number of gangs within Maskwacis. During the writing of this article, a drive-by shooting occurred in the Samson townsite. ${ }^{7}$ The activity of these gangs is most visible in the Ermineskin and Samson townsites, which is technically the hamlet of Hobbema. The increase in gang activity has also resulted in a dramatic increase in the number of police resources devoted to the community. In the summer of 2008, Maskwacis was named as having the highest concentration of gang members per capita in the country. ${ }^{8}$

Gang activity has some impact on Miyo Wahkotowin, but the people that I formally interviewed about restorative justice did not mention gangs. In my discussions with Wildcat he relayed that, rather than experiencing the direct presence or influence of gang activity, the schools have to deal with students who have alleged gang affiliations for the purposes of bullying and intimidation. Although some students represent themselves as gang members, ${ }^{9}$ less than 2 percent of the school population exhibits this aggressive form of behaviour.

While gangs represent the outward face of violence in the community, there is a pervasive and systemic level of violence and conflict in the community that is not reported in the media. The relatively hidden face of violence takes the shape of physical, sexual, mental, and emotional abuse or neglect. It also encompasses the numerous antagonistic relationships and

Indian Policy, 1969 (Ottawa: Queen’s Printer, 1969).

Reaction to any form of Indigenous protest usually illustrates this. For example, the ongoing and persistent battle over resource extraction and the ability of Indigenous peoples to decide what activities takes place on their lands illustrates the issue of dominance. Even in the case of Fish Lake, where Indigenous peoples claimed a minor victory because a mining development was stopped, the development was actually stopped for environmental reasons and not because Tsilquotin people are allowed to decide what takes place on their land.

6 “10 named to residential school 'survivor' group” CBC News (15 July 2009), online: CBC News $<$ http://www.cbc.ca/news/canada/edmonton/story/2009/07/15/trc-survivor-cttee.html>. The comment was removed from the board on 16 July 2009.

"Hobbema, Alta. man critical after drive-by shooting” CBC News (29 November 2010), online: CBC News < http://www.cbc.ca/canada/edmonton/story/2010/11/29/edmonton-hobbema-drive-by-shooting. html $>$.

8 "Former Hobbema gang member hopes to make difference” CBC News (15 May 2008), online: CBC News <http://www.cbc.ca/canada/calgary/story/2008/05/15/cgy-hobbema-gangs.html>.

$9 \quad$ It is unknown how many students are actually gang members, and the school attempts to avoid labelling students in this way. 
deep-seated conflicts that take place in the community. This is all exacerbated by high rates of poverty and poor health, which silently prevent people from living their lives with dignity.

To date, no major study has been done to guage the effect of residential schools on Maskwacis, but there is no doubt in the minds of people here that the intergenerational trauma discussed in the literature on residential schools applies to Maskwacis. While it would be impossible to quantify the amount of violence and conflict that takes place in Maskwacis, it is more likely that the majority of violence in the community stems from the residential school system, and not from gang activity. As Andrea Smith states: "I have attended several Native wellness workshops in which participants are asked to draw a family tree that shows the generation in their family in which violence, substance abuse, and other related problems develop. Almost invariably, these problems begin with the generation that first went to boarding school."10

\section{B. Political LANDSCAPE}

The effects of violence and conflict in the community should be understood as one of the major challenges facing Miyo Wahkotowin. In addition to community violence, it is also important to examine the larger landscape of power, authority, and legitimacy in which the community exists. I will refer to this encompassing set of issues as the "political landscape" of Maskwacis, and attempt to describe how this political landscape engenders a lack of cooperation. Here, power refers to the ability of people to influence the actions and decisions of collectives and individuals. Authority refers to the designation or authorization to make decisions on behalf of a position or office. Legitimacy, in a collective sense, refers to people actively, rather than coercively, binding themselves together in relationships in order to carry out, and be subject to, group rules and decisions. In an individual sense, legitimacy refers to the widespread respect and prestige someone holds among others as a result of a record of prudent and scrupulous behaviour.

To understand the political landscape in Maskwacis we must first understand the primacy placed on band governments within the political landscape of First Nations people. Literature over the last 30 years on the governance of reserve communities has focused on the elusive concept of self-government. The ideas contained in the concept of self-government were first articulated extensively by the Federation of Saskatchewan Indians in their 1977 "Indian Government Paper." ${ }^{\prime 11}$ The concept of self-government was used to signify the inherent right of Indigenous peoples to govern their own affairs over their lands and a desire on the part of First Nations peoples to imbue their governing institutions with Indigenous values, structures, and practices. It was also thought by most commentators on the issue, Indigenous and non-Indigenous alike, that not only was reviving Indigenous forms of governance a just and right thing to do, it was also a necessary prerequisite for good governance. ${ }^{12}$ As such,

10 Andrea Smith, Conquest: Sexual Violence and American Indian Genocide (Cambridge: South End Press, 2005) at 44.

11 Yale D. Belanger \& David R. Newhouse, "Reconciling Solitudes: A Critical Analysis of the Selfgovernment Ideal” in Yale D. Belanger, ed., Aboriginal Self-Government in Canada: Current Trends and Issues, 3d ed. (Saskatoon: Purich, 2008) 1 at 2, 7-8.

12 The Harvard Project on American Indian Economic Development has been central in elucidating the concept of a cultural match. They have numerous articles that can be accessed online: The Harvard Project on American Indian Economic Development <http://hpaied.org>. See also Menno Boldt, Surviving as Indians: The Challenge of Self-Government (Toronto: University of Toronto Press, 1993). 
achieving self-government became one of the main, if not primary, political expressions of self-determination for Indigenous peoples.

While further research is needed on this topic, it appears as if the political vehicle through which First Nations peoples would have self-government bestowed on them is the 600 plus band governments across the country as legislated by the Indian Act. ${ }^{13}$ The problems with the Indian Act seem almost endless. It is one of the most amended pieces of legislation in Canada, and it is outwardly and unabashedly paternalistic. Despite its inherent problems, it is potentially the most resilient and obstinate piece of Canadian legislation. As such, one of the major goals of self-government is the removal of the Indian Act. Despite the large amount of attention paid to the idea of self-government, little attention has been paid, either from First Nations leaders or academic commentators, to how power, authority, and legitimacy operate in band governments across the country. It is as if the problems of First Nations governance will end with the removal of the Indian Act. The community of Maskwacis provides a largely, but not entirely, unique situation because four bands, all with their own governing apparatus, exist side by side in one community. This situation illuminates what I believe are some of the worst aspects of power, authority, and legitimacy within Indigenous communities.

Vital to understanding the political environment that Miyo Wahkotowin operates in is the fundamental shift in power that occurred after Indigenous peoples moved onto reserves. In the pre-reserve era, people accessed and exercised power by building up a reputation of legitimacy. Those with reputations of legitimacy would attract a following of people, thus forming a political collectivity. The political collectivity would change in numbers dependent on the seasons, but would also wane or grow in size depending on the competency of the leadership. These political collectivities were not permanently settled year round, and would come together to form large encampments in the summer, which also gave people the opportunity to join a different political collectivity depending on which encampment they joined. All positions of authority were temporal and would only crop up for specific purposes, although a reputation of legitimacy was held year round. Those deemed to be illegitimate leaders would quickly lose their following and any power they might have held. ${ }^{14}$

In the reserve era people now access and exercise power by occupying positions of authority within the geographically fixed and centralized authorities of band governments. The Chief and council members are the most visible form of this authority, but people also

R.S.C. 1985 , c. I-5.

See e.g. Robert Innes, "Multicultural Bands on the Northern Plains and the Notion of 'Tribal' Histories" in Jarvis Brownlie \& Valerie Korinek, eds., Finding a Way to the Heart: Feminist Writings on Aboriginal and Women's History in Canada (Toronto: University of Toronto Press) [forthcoming]; Sharon Venne, "Understanding Treaty 6: An Indigenous Perspective” in Michael Asch, ed., Aboriginal and Treaty Rights in Canada: Essays on Law, Equality, and Respect for Difference (Vancouver: UBC Press, 1997) 173; Theodore Binnema, “Old Swan, Big Man, and the Siksika Bands, 1794-1815” (1996) 77 Canadian Historical Review 1; Marie Smallface Marule, “Traditional Indian Government: Of the People, by the People, for the People” in Leroy Little Bear, Menno Boldt \& J. Anthony Long, eds., Pathways to Self-Determination: Canadian Indians and the Canadian State (Toronto: University of Toronto Press, 1984) 36; Hugh A. Dempsey, Big Bear: The End of Freedom (Vancouver: Douglas \& McIntyre, 1984); Leroy Little Bear, “Jagged Worldviews Colliding” in Marie Battiste, ed., Reclaiming Indigenous Voice and Vision (Vancouver: UBC Press, 2000) 77; John S. Milloy, The Plains Cree: Trade, Diplomacy and War, 1790 to 1870 (Winnipeg: University of Manitoba Press, 1990) at 63-82; Russel Lawrence Barsh, "The Nature and Spirit of North American Political Systems" (1986) 10 American Indian Quarterly 181. 
hold authority by occupying various decision-making positions within a band. While the vast majority of people who hold positions of authority within bands have worked hard to reach those positions, their power is still largely dependent upon holding a position of authority.

These two vastly different political landscapes are not mutually exclusive of each other, but this shift is profound insofar as the political context within which Miyo Wahkotowin exists. Whether through an implicit or explicit recognition of the situation, this shift in power is not lost on the people of Maskwacis. Many people, families, and networks have been incredibly adept at occupying and holding onto positions of authority. While the following statement is not indicative of everyone, the result has been that people have oriented their actions and decisions towards grabbing onto and holding these positions of authority. This is a strategy that does not end when people have successfully established themselves in positions of authority, and leads to a political landscape that often fosters selfish and shortsighted actions. It is also aided by a practice whereby the band government is largely treated as a resource distribution centre. As such, those in positions of authority may speak rhetorically about improving the lot of the community, but band governments struggle to provide effective public services for their communities. Often the extent of the authority of bands is to oversee the distribution of the bands' budget.

The second effect that the language of self-government has nourished is that, overwhelmingly, political leaders have begun to equate the authority held by band governments as the same sovereign authority held by independent nation states: that is, exclusive and ultimate authority over a bounded piece of territory. For example, the vision statement of the Ermineskin Cree Nation 2009-2010 strategic planning document states that "Ermineskin Cree Nation is strong, healthy, united and sovereign." 15

When viewed from a history of colonialism and a desire to build relationship with Canada on the foundations of Treaty 6, the language of sovereignty may well be the best option available. Yet, the relationship with Canada and its provinces and municipalities is not the only relationship that band governments need to take into consideration. It is also important for band governments and Indigenous peoples to have the ability to interact with each other, form alliances, and consolidate authority between communities when beneficial.

As a result of the unexamined language of sovereignty, the four bands in Maskwacis relate to each other from the standpoint that each jurisdiction holds its authority to the exclusion of the other three. Spurred on by this conception of authority, the people charged with carrying out the functions of each band take minimal steps to interact and collaborate with the other bands. For the most part, each band operates their own, almost identical services, side by side, and little effort is put into collaboration. The idea of merging authority with each other over certain areas of shared interest is, for the most part, off the table.

Again, this situation is complicated by individual orientations toward gaining control of and holding positions of authority. The prospect of the bands merging authorities with each other over shared concerns becomes even more politically unfeasible when viewed from the perspective that a significant amount of people would lose their positions of authority. 
Powerful networks would have their power, and their ability to concentrate numerical strength within a band, further eroded under a situation of four-band collaboration. As well, a number of non-native people working within Maskwacis, who could also potentially lose their positions, also work against four-band collaboration. What is on the line is not simply a matter of how to best politically organize as a singular community, but also the comfortable positions some people and networks have carved out for themselves within band governments and the related colonial political infrastructure. With this in mind, let us not forget that Maskwacis is a very impoverished community and the prospect of losing one's hold on a position of authority is not simply a matter of getting another job; it could potentially impact the ability of people to put food on the table.

There are examples where four-band collaboration does exist, most notably the existence of the Four-Band office, Maskwacis Health Services, and Maskwachees Cultural College. Yet, even the Four-Band office was mainly in place to distribute oil money from the collective land holdings of the four bands. As the oil money is close to drying up, discussions have even been held regarding the disbandment of the Four-Band office. Maskwacis Health Services and Maskwachees Cultural College offer great potential for collaboration, but often receive little support from the band governments in Maskwacis. Other acts of collaboration have been minimal and of insignificant effect.

Despite this, the schools in Maskwacis have recently started collaborating with each other. This began in the summer of 2010 with a shared orientation day for staff members, a tradition that will hopefully continue into the future. Also, a grant received by Miyo Wahkotowin from a federal government program, First Nations Student Success, is in the process of being turned into a collaborative four-band initiative between the schools. Despite these early signs of progress, the fact remains that Miyo Wahkotowin and the other schools still exist in a community environment where effective collaboration is the exception to the rule and, as such, each band continues to run their own school to the exclusion of the others.

Additionally, the two aspects above are further complicated by a static, concrete, and rigid set of membership codes. Marriage between people from different bands is common. When this occurs in Maskwacis, potential problems can often be mitigated if a child's parents stay together. But if a child's parents separate, the child's primary residence and kinship networks may be different from their official band membership. This scenario can result in difficulty obtaining services from their official band. This situation becomes even more complicated when a community member's official band membership lies with a band outside of the four bands at Maskwacis. For instance, 5 percent of the students who attend a Miyo Wahkotowin school have band membership from outside the four bands, despite living in Maskwacis. ${ }^{16}$

Miyo Wahkotowin maintains a strict rhetoric that states that a Miyo Wahkotowin student is a Miyo Wahkotowin student regardless of their band membership. Still, their job of providing extracurricular and additional services for students is made difficult by the political landscape of membership. Bands in Maskwacis have a number of departments that provide funding to people for extracurricular activities. Not only do non-Ermineskin band member students have a more difficult time obtaining extra funding for school activities, but 
Ermineskin band members whose children attend school off-reserve complain about giving help to Miyo Wahkotowin students.

While more research is needed, one could argue that band membership is largely seen as a designation through which one receives entitlements, and is not a designation that is based around reciprocal obligations and responsibilities toward one another. ${ }^{17}$ I was once told a story involving a discussion the Samson Band was having regarding its band membership rules. One person suggested that they be called "citizenship rules,” but this suggestion was put aside on the grounds that if the band was to be based on the idea of citizenship, then it would have to develop more accommodating and fluid rules that incorporated people who joined the community. ${ }^{18}$ As such, having a dynamic and open conception of how people within Maskwacis can relate to one another, form relationships, and create political collectivities is completely confined and restricted by a pervasive and static conception of membership.

Finally, Miyo Wahkotowin is tasked with trying to revive schools for Indigenous peoples after a hundred years of federal government-controlled schooling, most prominently the generations of children “educated” in residential schools. Reviving pre-colonial conceptions of education in this situation is almost impossible because Nehiyaw ways of life have been severely disrupted and Nehiyawewin (the Cree language) is spoken fluently by only a minority of the community. Furthermore, contemporary pressures mean that the majority of parents want their children educated by the provincial curriculum, and those who would opt for a radically alternative Nehiyaw education would have to admit that their children's choices afterward would be severely confined due to the lack of land on which people might exercise traditional lifestyles. Nor are there Indigenous institutions that have the ability to train and instruct competent youth educators. With this final caveat we can now look at Miyo Wahkotowin's restorative justice initiative.

\section{Restorative Justice AT THE MIYo WAHKOTOWIN COMMUNITY EDUCATION AUTHORITY}

To find out more about the restorative justice initiatives employed at Miyo Wahkotowin, two methods were used. First, a questionnaire was sent out. The intention of the questionnaire was not to solicit data, but to give the organization an overview of what questions the research would ask. The questionnaire allowed for interview participants to think about Miyo Wahkotowin's restorative justice initiative and prepare for the interview. Second, two interviews were conducted. In addition, a number of short follow-up visits were conducted with the staff to clarify information and receive updates. The overarching query that guided data collection was: "How is restorative justice conceptualized in relation to the daily operation of the Miyo Wahkotowin Education Authority?" The staff who were interviewed read the questionnaire beforehand, but the interviews were conducted in an open-ended fashion. 
One of the two interviews was conducted with members of the central office staff, Wildcat, and Mehal. The Ehpewapahk Alternate School's principal, Wendy Solland, and one of the school's students were also present for part of the interview with Wildcat and Mehal. The second interview was conducted with the Ermineskin Junior/Senior High School principal, Keith MacQuarie, and vice principal Seright. The interview with the central office staff mainly focused on the intervention hearings, and the interview with the Junior/Senior High School staff mainly focused on the mediation processes that take place in school.

The restorative justice initiative at Miyo Wahkotowin will be explained in six sections. The first two sections will look at the operation of Miyo Wahkotowin. These sections cover programming and support services, along with intervention hearings and mediation. The next three sections outline the three themes that emerged from the interviews. These themes include restorative justice as being relationship driven, restorative justice as a language to think about discipline, and restorative justice as a culture. In the final section, the student's experience with the restorative justice initiative is explained.

\section{A. Programming and Support Services at the Miyo Wahkotowin COMMUNITY EDUCATION AUTHORITY}

Miyo Wahkotowin oversees three schools. The Ermineskin Elementary School delivers education from K-6, the Ermineskin Junior/Senior High School runs from grades 7-12, and the Ehpewapahk Alternate School delivers a specialized program for students aged 14-19. ${ }^{19}$ Over the past four years, Miyo Wahkotowin has maintained a total enrollment of approximately 950 students. In addition to its regular programming, Miyo Wahkotowin also takes great pride in its sports teams and recently received a large grant from Heritage Canada to develop an online Cree dictionary. ${ }^{20}$ Miyo Wahkotowin also received a glowing review in an Edmonton Journal article, which was the last article of a four-part series looking at the poor results of Edmonton area band-controlled schools. ${ }^{21}$ Despite its success, the system still deals with old issues; notably, poor attendance and, of course, disciplinary problems. Programming is currently split into four streams with nine academic programs not including the K-4 and K-5 programs. The programming is in a transitional era and will likely undergo more changes after further review. ${ }^{22}$

A number of supports are also set up around regular programming. One of the key supports is the innovative Sohki program. This program is targeted at students whose "behaviour is affecting their learning." ${ }^{23}$ Students in the program spend most of the morning in their regular classroom. The Sohki coordinator moves between classrooms to observe the

Ehpewapahk Alternate School did admit one 13-year-old student this year because the Junior High program was not working for the student anymore.

See Canadian Heritage, News Release, "Ensuring the Preservation and Promotion of the Cree Language: The Government of Canada Supports Online Language Portal” (19 March 2009), online: Canadian Heritage <http://www.pch.gc.ca/pc-ch/infoCntr/cdm-mc/index-eng.cfm?action=doc\&DocIDCd=CR082 $611>$.

See Elise Stolte, “Ermineskin students find oasis of calm in a stormy place: School’s steady, relentless approach as model for First Nations” Edmonton Journal (27 September 2010), online: Edmonton Journal <http://www.edmontonjournal.com/news/Ermineskin+students+find+oasis+calm+stormy+ place/3548979/story.html\#ixzz10ebCpOvX>.

See Appendix B for more information on Miyo Wahkotowin’s programming. Interview of Sanila Mehal (2 December 2010), Hobbema, Alberta. 
behaviour of the students. After lunch, students return to the Sohki classroom and the Sohki coordinator works on behavioural issues.

All of the programs and supports are oriented towards finding solutions that address the unique needs of students in a supportive and appropriate environments. Miyo Wahkotowin operates on a philosophy of differentiated learning. With few other successful models to draw upon flexibility and adaptability is the order of the day, as they are constantly working on unique and innovative ways to provide education for their students.

\section{B. INTERVENTION HEARINGS AND MEDIATIONS}

Previously, when students were given a three-day suspension, one stipulation of the suspension was that the student could return to school only if their parents or guardians met with the teacher. A segment of students were not returning at the end of their suspension. Part of the reason these students were not returning was because their parents were reluctant to come in, and had feelings of guilt or shame about their child's misbehaviour. In effect, the rule was giving some students an unintended "mini expulsion." ${ }^{24}$ In response, the organization began to think about different procedures and supports that could be put in place for the disciplinary process. Ermineskin Junior/Senior High School stressed the need for additional support from the central office in situations where they felt that they had no further recourse to deal with students.

The central office staff began to look at intervention hearings as a support for Ermineskin Junior/Senior High School. The policy around intervention hearings had been developed in 2003, but it was largely an empty shell. Borrowing a number of concepts from restorative justice literature and training, 24 intervention hearings were held in the 2009-2010 school year. The format of the hearings was centred around how to generate solutions to the problems between the student and school community. At the end of the intervention hearing an agreement is drafted to help the student stay in school. In the agreement, both the student and school have obligations to live up to, and all members present sign, the agreement.

In addition to the intervention hearings, the restorative justice movement also coincided with changes taking place at Ermineskin Junior/Senior High School. There, Seright would conduct a mediation any time a student was sent to the office for misbehaviour. As Seright became familiar with the mediation process she began listening to the perspectives of the students, and started to empathize with their side of the story. During this time, Seright was learning about restorative justice and decided to incorporate the teachers into the mediation process. When Seright began to do this she realized that the perspectives of the teachers were not lining up with those of the students. Borrowing methods from restorative justice and other training, Seright began to focus more on fostering an environment where students could talk with the teacher and other students to work out the source of conflict. Instead of focusing on how to deliver punishments, the question became: "How can we all win in this situation?"25 
From the interviews, three major themes emerged around how the interview participants think about and practice restorative justice. These themes are: (1) restorative justice as being relationship-driven, (2) restorative justice as a language to think about discipline, and (3) restorative justice as a culture.

\section{THEME ONE: Restorative Justice As Being RELATIONSHIP-DRIVEN}

When Ermineskin First Nation was transferred authority over its schools from federal control, the Ermineskin school authority was titled Miyo Wahkotowin. Literally translated, "miyo wahkotowin" means "good relations," but this does not capture the full spectrum of ideas associated with miyo wahkotowin in Nehiyawewin. Wildcat states that "miyo wahkotowin is a Cree philosophical concept about people getting along, and maintaining healthy relationships with each other.” The concept of miyo wahkotowin is also at the heart of the school mission, which is "[t]o promote and follow MIYO WAHKOHTOWIN so that the Ermineskin schools are safe, caring and happy places, where every child is encouraged and supported in their exploration of the world."26 As MacQuarrie stated, "whoever came up with Miyo Wahkotowin as a name is brilliant ... it does not matter what aspect of the school you look at, academics, attendence, parents, it’s all based around relationships.”27

Wildcat states that the question they always have in their discussions at the school is "What is it about this school that makes it a Cree school?" This question always returns to the idea that it is based on the way that you treat people in the school. When Miyo Wahkotowin started to learn about restorative justice, it helped them to work on the question: "How do we make things fit into the belief we're a Cree school?" As the group began to learn more about restorative justice, they realized that it was simply part of the larger vision and mission of Miyo Wahkotowin.

All of the people interviewed said that the school had been practising restorative justice before they were introduced to the concept, but its practice had been patchwork and haphazard. Despite having elements of restorative justice, the disciplinary system was still a consequence-based process and the schools were seeing incidents involving the same students over and over again. When Miyo Wahkotowin revived the intervention hearings, the concepts of restorative justice helped move the process from being punishment-based to relationship-based.

Talking with a student in an intervention hearing is seen as necessary to building a relationship. Accordingly, all parties participate in the discussion at the intervention hearing. Every individual present talks about how the student's actions have affected them, regardless of whether they are a staff member who was directly involved, a family member, or board member. A family member is required to be present at the hearing because part of ensuring a successful process is ensuring that there are people outside of the school who can provide the students with support. Also, as Wildcat and Mehal explain, having a family member present helps to ensure that students do not misrepresent their family, and helps ensure honesty. 
A major goal of the intervention hearings has been trying to provide an atmosphere where students can feel free to speak honestly. Unless students are able to speak comfortably about what they want for themselves, it is difficult for Miyo Wahkotowin to put measures in place that help students move towards a healthy future. Having the student speak freely is seen as an integral part of the school living up to its obligation to put supports in place for the student.

Even the explusion hearings, according to Mehal and Wildcat, are reorienting themselves towards "patching up" the relationships and "reconnecting students with the school." Previously, as Wildcat explains, the expulsion hearings revolved around the idea that "you're either in or you're out.” Miyo Wahkotowin staff "would almost expect students to show up at an expulsion hearing” with a defensive attitude. If a student was not expelled as a result of their expulsion hearing there were no further steps in the process. As well, Mehal explains, the in or out expulsion process was not fair to the community because the school was simply sending the student and the issues they were encountering to another segment of the community by forcing them out of the school system. Now, all of Miyo Wahkotowin's disciplinary process conveys a sense of building a school community and creating citizens of the school community, with a view that citizenship in the school community will have a positive effect in the remainder of the community.

\section{Theme Two: Restorative Justice As A LANGuAge TO THINK ABOUT DISCIPLINE}

The interviews all touched on the idea that elements of restorative justice were already being practised, they just "didn't have a name for it." ${ }^{28}$ In attempting to move toward a relationship-based rather than a consequence-based approach to discipline, lacking a language to describe restorative-based discipline was a major obstacle. When staff members first went to a restorative justice workshop, it reinforced the idea that they were heading in the right direction and reaffirmed that relationship-based discipline was a better way forward. ${ }^{29}$ The interview participants also felt that having a language to talk about restorative justice helped them to communicate the ideas of restorative justice when talking with other staff members and students. They felt that having a common language to talk about discipline was an important aspect of "equipping people with the tools to practice restorative justice in an everyday sense.”30

Another one of the major benefits of their restorative justice training has been that the language and concepts of restorative justice have opened up new ways for staff to think about discipline. One way that restorative justice has helped people change their thinking is by clarifying the distinction between questions such as "what fits the crime?" and "how can we repair the harm that's done?” MacQuarrie stated that "[r]estorative justice is realizing that not one size fits all, and that fair doesn't necessarily mean equal.” Wildcat and Mehal talked about how expulsions used to be a way to send a message, and now they ask "How do we

Ibid.

Ibid.

Supra note 16. 
repair the harm that's done and take into account that everyone and every situation is different?”

In order to break out of one-size-fits-all thinking you need to be creative about how you approach each situation, and creativity requires people to exercise and develop their critical thinking skills. In mediations that take place at Ermineskin Junior/Senior High School, a restorative justice approach has forced people to think more critically because they have to ask themselves the question: "How can this relationship be repaired and work in the future?," instead of: "What punishment fits the transgression?" 31 Asking how the relationship can be repaired has helped the staff and the students to think more critically about discipline. Also, as Mehal stated, critical thinking and healthy relationships complement each other because "no significant learning can happen without a significant relationship."32 Inversely, when an unhealthy relationship is present, critical thinking will be lacking.

MacQuarrie gave an example of how restorative justice has helped him to think more critically about discipline. He stated that he still believes in suspensions, but he has reevaluated the punitive rationale. In the case of physical altercations, he still believes a threeday suspension is appropriate because it gives the students involved time to cool off. On the other hand, a student who was caught intoxicated at school was previously issued a three-day suspension. Now they are issued a suspension for the remainder of the day. When they return to school the following day they are given education on the harms associated with drugs and alcohol. While creative discipline is more difficult, the staff believe that creative thinking at the beginning of the process will result in improved outcomes down the line.

The interview participants also talked about some of the downfalls related to using the language of restorative justice. One of the issues that they have had to confront is that people, particularly parents, had a bias against restorative justice because it was not consequencebased. In my interviews with the Miyo Wahkotowin staff we discussed how, because the criminal justice system is punishment-based, people have come to equate the only form of serious discipline with punishment-based outcomes. Operating within this discursive climate even influenced the name of the intervention hearings. When discussing the content of the hearings, one suggested option was to name the hearings "restorative justice circles." This was decided against because there was a feeling that parents and students might not take the process seriously under this title. Further, “intervention hearing” implied a greater level of formality. ${ }^{33}$ As well, even though the process of the intervention hearing has become relationship-based, the agreement that is produced still has a punishment and consequencebased tone. Again, the change in process has still been hampered by an overall climate where discipline is equated with punishment.

\section{E. THEME THREE: Restorative Justice As A Culture}

The final theme that emerged from the interviews is how the interviewees viewed restorative justice as a concept that should be woven into the fabric of daily interaction at the 
school. The interview participants had a vision of the future where all members of the school, including students, parents, and staff, can converse in the principles of restorative justice. To signify that everyone should be involved in the process, the people interviewed began using the term "citizen" to signify that, as a citizen of the Miyo Wahkotowin community, you have a responsibility to participate in the governance of the school. To reach the future they envision, the interviewees stressed that a significant amount of time would need to be invested in the process.

Investing time in building restorative justice would need to take place in two ways. First, the idea of restorative justice must be spread so that all members of the school community understand its principles. As Wildcat said, "the process must be demystified so everyone can act on it; restorative justice should be leadership training and citizenship building for all students.” To illustrate the point, Wildcat explained that, previously, the expulsion hearing was set up with specialized knowledge, with the result that only a few understood the process well. Those who understood the process held all of the power, and they could use the expulsion hearing as a tool against students. On the other hand, according to Wildcat, restorative justice is about everyone holding the necessary tools and everyone being able to participate in the process as citizens acting together.

Second, time must be invested to address conflicts when they arise in order to prevent further escalation. It was hoped that utilizing restorative justice approaches would lead to the schools and parents talking to each other and tackling situations at the "immediate level." One participant stated that the "main restorative justice work would take place in the classroom" on an ongoing basis. ${ }^{34}$ The interviewees also referred to this as "improving the front end of the process" in order to eliminate expulsion hearings down the line. Supports will also be needed to ensure that mediations actually take place, and students cannot avoid restorative justice work. Mehal and Wildcat also talked about the administrative procedures that the organization will need to set up so that intended intervention hearings can be tracked and take placed in a timely fashion. This means that people need to treat restorative justice work as a priority and spend the necessary time to implement these procedures.

Wildcat and Mehal cited an excellent example that illustrates how much time needs to be invested in the process. In a student questionnaire, students had responded that they did not feel committed to participating in the disciplinary process because they did not feel that the school possessed the ability to ultimately resolve their conflict. In particular, the staff learned that, in many instances, bullying was not being dealt with because students did not feel that their situation would improve if they brought it to the attention of school staff. Moving toward a restorative justice-based model has had its difficulties, and is a time-intensive process. As MacQuarrie said, "restorative justice is not a quick fix, but a better fix."”35

Many impediments to restorative justice are still in place. Overwhelmingly, the interviewees cited that "old school" thinking about consequence-based discipline is ingrained within teachers and parents. As such, it is not simply a matter of spreading the ideas of restorative justice and expecting system-wide adoption. MacQuarrie talked about how people 
need to get out of the mindset of "that's the way it was for me growing up, and so that's what I'm going to do." ${ }^{36}$ As well, Mehal and Wildcat cited a recent example where a staff member had recommended that a student go through an expulsion hearing to "send a strong message." In response, they felt that the next step was moving to a place where restorative justice procedures are regarded as a serious process, in the same way as the old punishment model is regarded as a serious process. ${ }^{37}$

To get to this place, the interviewees talked about viewing the school as a community, and citizenship within the school community. When a relationship is damaged, the goal is to have a school culture that can effectively bring students back into the community. For example, Seright talked about a change in rationale behind why teachers send students to the office. There has to be a shift from sending students to the office to be punished, to sending students to the office so the principal can provide support to help them work out problems. The principals at Ermineskin Junior/Senior High School stated that even if teachers are practising restorative justice principles, if the teachers do not also shift their thinking the disconnect will limit the effectiveness of restorative justice within the schools. ${ }^{38}$

The interviewee also talked about the challenges they faced in trying to convince students that they are not in trouble. Generally speaking, punishment is the first thing students think about when issues arise, which is amplified "when teachers set it up that way." Yet some positive signs already exist. Seright said it has been amazing to watch the class of grade 10 students, who have now gone through relationship-based mediations for two years. When I talked to Seright, she related two incidents in the previous week where, for the first time, students said that they would go talk to the classmates they were having problems with on their own. ${ }^{39}$

\section{F. TALKING TO A StUdent}

In my meeting with Wildcat and Mehal, they invited Solland, the principal of the Ehpewapahk Alternate School, to join us. All three agreed that it would be useful to hear a student's perspective, so Solland invited one of her students, "Bruce," to present his experiences. Bruce is 18 years of age, and had been attending the the Ehpewapahk Alternate School for six years. He has a young child who is seven months of age, and Bruce's partner attends Ermineskin Junior/Senior High School. Ehpewapahk has a separate building with an enrollment of 45 students. Of the 45 students who started the year, 38 have attendance rates of 80 percent or higher. Students at the school work on literacy and mathematics, which are both individualized programs, and undertake a number of activities related to life skills. For instance, two of the students, including Bruce, attended restorative justice training shortly after I spoke with Bruce.

Bruce had recently gone through an intervention hearing over an incident where he had shown up to school intoxicated. This had happened once before and some of the staff members were visibly upset with him. Bruce responded with anger when they expressed their

Ibid.

Supra note 16.

Supra note 25.

Ibid. 
disappointment. After this incident, an intervention hearing was set. During this time, Bruce was asked to stay away from the school. As well, Bruce had gone to his brother's house in a rural part of the reserve, where no one could find him, so that he could stay away from negative influences. He phoned into the school every day to talk with an Ehpewapahk employee and maintain contact.

In describing the intervention hearing, Bruce said that he was able to actually speak for and explain himself. Bruce said, "it felt good to stand up for myself and explain myself." Bruce had said that he felt respected in the intervention hearing. When asked why this was, he said that it was “because everyone was listening.” In the intervention hearing, Bruce was able to talk about how he had a problem with anger, and sometimes had difficulty expressing himself because he would get mad. Part of what Bruce asked for in the intervention hearing was help dealing with his anger. As a result of the hearing, the school became obligated to help Bruce get counselling. All of the staff members involved with the previous incident also sat in on the hearing. This was an important aspect of the hearing because if the aggrieved staff members were not part of the agreement, it may have hindered or prevented Bruce from repairing these relationships. As well, restorative justice does not work if people are subjected to, or forced into, a position of reconciliation. In return, Bruce had to issue an apology to the staff members who were hurt by his previous actions, and work on repairing his relationship with them. Bruce also agreed to publicly apologize to the class. When asked how he felt about the hearing, Bruce said that he was happy to be allowed back to school.

Another outcome of the intervention hearing was that if Bruce feels his temper rising in class, he is allowed to leave the classroom to cool off without the staff asking where he is going. A staff member will then talk to him about what is agitating him that day. Other students with anger problems are also allowed to follow this rule, but the rule does not give students a universal pass to leave class whenever they like. Mehal had an excellent insight into this practice: the whole school district has moved to a focus on differentiated instruction, where the different learning needs of students are taken into account. This happens through the different programs that Miyo Wahkotowin offers, but can also take place within individual classrooms. In the case of Ehpewapahk, each student follows a tailored literacy and math program. Mehal stated, "we have differentiated instruction, why not differentiated discipline?"40

Solland also stated that Bruce was interested not only in repairing his relationship with the staff members, but also in "repairing the relationship with himself” through a sincere attempt to work on his anger issues. Bruce has since quit drinking, and has shown by his actions throughout the process that he wants to repair the hurt relationships and rejoin the school community. Ehpewapahk was happy to have Bruce back because he plays a leadership role with many of the others students. In Bruce's words, he helped "keep everyone in order” and encouraged students to work with him when they were working on assignments. According to Bruce, this was successful because they have a core group of students who have attended Ehpewapahk for two to three years and the students have developed a community atmosphere within the school. 
Another aspect of the hearing was that Bruce was very honest about what had happened. Previously, students used to attend hearings to defend themselves, and the environment was very confrontational. The administrators said that part of what they are learning is that they need to provide a safe environment for students so that the students can tell their story. Unless school staff can understand the root causes of a student's behaviour, it is impossible to understand the student's perspective and effectively use the principles of restorative justice.

Bruce has also recently participated in the criminal justice system. During Bruce's trial he was given the option of holding the hearing in Wetaskiwin instead of Edmonton, but only if he agreed to plead guilty. Since Bruce did not have reliable access to transportation he agreed to do this, and was given a set of conditions that he had to fulfill as part of his sentence. Bruce clearly understood the difference between the restorative justice and criminal justice processes. He stated that "in the court system a lawyer does all the speaking for me, and explains what is happening. Even if I could speak, they probably wouldn't have listened to me anyways." Any empathetic person talking to Bruce could see that he had a sincere desire to have good relations with people. When asked about his future, Bruce said that he wants to coach sports and have good relationships with his family.

A week after my interview with Bruce, I heard that he, along with another student and two Ehpewapahk staff members, had taken restorative justice training with the Samson Band's legal department. After taking this training, Bruce was asked to help sit in on a restorative justice circle with two students. A serious incident had occurred the year before where one of the students had brought a weapon into the school and injured another student. While the offending student received punishment, he was allowed back into school the following year. From the school's perspective, the offending student had undergone his punishment and was now allowed back, but from the injured student's perspective nothing had changed except for the fact that the offending student had left for a couple of months.

The school noticed that the injured student had started acting out in class, which was unusual behaviour for him. When the student was asked what was wrong, he explained the sense of injustice that he perceived about the entire situation. The elementary school decided to hold a restorative justice circle and asked Bruce, fresh off his training, to participate in the situation. The school counsellor involved stated that Bruce helped to communicate many points that the students may not have taken seriously had it come solely from a staff member. ${ }^{41}$ For example, Solland explained that the school counsellor was telling the students that it takes more courage to walk away from a fight. When Bruce spoke up and explained to the students why he agreed, the students responded to the message coming from someone that they identified with. ${ }^{42}$ Bruce said that through the restorative justice, the boys realized that the reason they had begun fighting in the first place was because of rumours.

Of course, the seriousness of the issue between the two students means that months, or potentially years, will have to pass before we know if the students have repaired their relationship. Restorative justice is not some magic elixir that will cure all. Yet this story does 
illustrate how the restorative justice program at Miyo Wahkotowin was progressing even as this article was being written. With this in mind, let us conclude with a look at the utility of restorative justice at Miyo Wahkotowin.

\section{RESTORATIVE JUSTICE AND CITIZENSHIP}

This article started with a brief outline of violence, conflict, and some of the main impediments to collaboration in Maskwacis. I would like to end by suggesting that the true benefit of the restorative justice work at Miyo Wahkowotin lies in the shaping of different subjectivities for the citizens of Maskwacis. Many people have told me that "people have to change their attitudes before change can happen in this community." This sentiment, expressed by many, is what I mean when I say that we must shape different subjectivities in the citizens of Maskwacis. The following will draw upon the intellectual resources of my community, family, and Miyo Wahkotowin, in addition to intellectual resources from academia to look at restorative justice as a citizen-building activity.

In "Subjects of Empire: Indigenous Peoples and the 'Politics of Recognition' in Canada,”43 Glen Coulthard argues that one reason the politics of recognition will not fundamentally alter the colonial relationship between Indigenous peoples and Canada is that, when recognition is extended to Indigenous peoples, it has the effect of subtly shaping and altering their world views and subjectivities. This is because recognition does not take place on an equal playing field between Canadian and Indigenous peoples, but rather an unequal playing field where Canadian actors are able to effectively maintain their position of colonial dominance while extending rights, benefits, and recognition to Indigenous peoples. As Coulthard himself elucidates:

The problem here, of course, is that these fields are by no means neutral: they are profoundly hierarchical and power-laden, and as such have the ability to asymmetrically mold and govern how Indigenous subjects think and act not only in relation to the topic at hand (the recognition claim), but also to themselves and to others. $^{44}$

I would suggest that the three impediments to political collaboration I listed above — the shift in power from pre to post-reserve Nehiyaw society, the emulation of nation-state sovereignty, and the freezing of band membership rules - represent the slowly built-up effects of years of colonialism seeping into and affecting the mindset, or subjectivities, of the citizens of Maskwacis. With this in mind, I would suggest that the transformative potential of restorative justice at Maskwacis lies largely in imbuing a new conception of citizenship within the Miyo Wahkotowin community, but specifically in the students of Miyo Wahkotowin. If one of the strategies of self-determination necessarily involves transforming people's subjectivities away from the distrust and discord that now exists as a result of decades of colonial interference, Miyo Wahkotowin offers us a light through the tunnel. In this sense, I adopt the conception of diverse citizenship proposed by James Tully. In his chapter entitled “On local and global citizenship: an apprenticeship manual,” a culmination 
of Tully's impressive body of scholarship, Tully outlines two broad formations of citizenship. ${ }^{45}$ The first, and more powerful form of citizenship in the world today, is what Tully calls "modern citizenship." Modern citizenship is equated with the citizenship in modern states and the corresponding "cosmopolitan" citizenship in the institutions of globalization. ${ }^{46}$ On the other hand, and often in opposition to modern citizenship, Tully outlines another broad formation of citizenship which he calls "diverse citizenship.” Diverse citizenship encompasses the multiple and diverse ways that people form communities, and "presents citizenship as a situated or 'local' practice that takes countless forms in different locales." ${ }^{\text {"7 }}$ As such, when Tully evokes the term "citizen," he does not refer to participation as a member of a country like Canada. Rather, Tully's definition of citizen, both modern and diverse, is "a person who is subject to a relationship of governance (that is to say, governed) and, simultaneously and primarily, is an active agent in the field of a governance relationship." ${ }^{\not 8}$ In other words, Tully's conception of citizenship encompasses any instance where people participate in relationships with others in order to make decisions over shared actions.

Miyo Wahkotowin necessarily lies at a crossroads between the modern and diverse forms of citizenship; it is a formal institution of education that relies primarily on the funding and curriculum of the Canadian state, yet it also possesses the ability to make autonomous decisions and provide education separate from the provincial school system. Furthermore, Miyo Wahkotowin lies within a stream of diverse citizenship because the people of Maskwacis retain their indigeneity and independence, both of which provide a degree of separation from Canadian citizenship.

Some may be inclined to hold up the work at Miyo Wahkotowin as an exemplar of how band-controlled schools can organize themselves. While doing so may have benefits, it would also bring the observations offered here back within the realm of modern citizenship and its participation in the institutions of band governments and ultimately integration into the Canadian state. Those band-controlled education authorities, similar to Miyo Wahkotowin, who are able to set up and practice strong governance would definitely benefit from understanding the practices of restorative justice outlined above. Yet, ultimately, it is the institutional order on reserves and its intertwined set of attitudes and orientations that prevent co-operation and collaboration. As such, change will not be a simple matter. Reforming the present system will necessarily involve looking beyond band governments as the political vehicle that will help Indigenous peoples move toward self-determining existences. This does not mean that we cannot work within, against, and beside the institutions of band governments, but reform of these institutions should not be the primary focus of our energy. Rather, as Nehiyaw peoples and Maskwacis residents, we must broaden our conception of citizenship to a place where our focus is on forming relationships of governance with each other in the pursuit of shared practices and values.

Ibid.

Ibid. at 3 [emphasis in original]. 
I have titled these alternate forms of Indigenous governance "formations of legitimacy." It is in these formations of legitimacy that Indigenous peoples find their best hope for selfdetermination, and also for reinvigorating and reviving Indigenous legal orders. Here, the restorative justice initiative at Miyo Wahkotowin holds potential for the community of Maskwacis because it is shaping subjectivities toward a conception of citizenship that will help foster these formations of legitimacy. These formations of legitimacy will likely have the following characteristics:

(1) they should draw their strength from people coming together to pursue shared practices;

(2) they should endure in a relatively stable, yet flexible manner;

(3) they should not be dependent on one person or a small enclosed group of people for their continued success;

(4) they will often rest upon existing norms, values, and practices within Indigenous communities that can be traced to pre-reserve times;

(5) they should emulate the non-coercive, non-hierarchical, and consensual aspects of pre-reserve societies;

(6) they should exist in relation and in tandem with other formations of legitimacy, both within and between communities. This will involve breaking down the current boundaries and conceptions we have of community today, and likely involve a revival of the dynamic aspects of community that existed in the pre-reserve era;

(7) they should be largely independent and able to resist or rub up against outside interference that is imperial in nature; and

(8) these formations of legitimacy should not be based on constraining freedom in other communities.

In the Maskwacis context, two interrelated aspects prevent formations of legitimacy from taking root. First is a legacy of violence, conflict, and poor health, which has been imbued in the community as a result of colonialism. These can be thought of as explicit or overt forms of dysfunction because they are easy to see within the community. On the other hand are the three attitudes I have outlined that prevent co-operation and collaboration. These forms of dysfunction are implicit and incredibly difficult to see and comprehend. On both counts, the restorative justice initiative and the form of citizenship it advocates will help to overcome these obstacles to creating formations of legitimacy.

In consideration of overcoming the explicit forms of violence and dysfunction in the community, restorative justice holds potential for the hope of repairing relationships and helping to work through conflict before it escalates. Yet this explicit form of dysfunction will be difficult, if not impossible, to overcome if we cannot imbue the political field of our community with legitimacy. As such, I would like to spend the remainder of the article 
looking at how restorative justice holds potential for altering subjectivities and imbuing a new form of citizenship in the community.

Two stories related to me by Miyo Wahkotowin staff illustrate implicit forms of dysfunction. First, I had a casual conversation with Mehal where I had talked about some of the difficulties with co-operation and the sharp divisions that existed within Maskwacis. When I conducted the formal interview, she brought up how our earlier conversation had reminded her of terrible fights that students from different bands used to get into at school because the students held such a strong distinction between the different bands. Today, students no longer talk that way.

Second, during my interview with Seright she mentioned that when she was growing up she was not cognizant of the idea that people in the community belonged to four different bands, or the idea of reserve boundaries. She had family and connections that went beyond the Montana Band, where her membership lies. Seright said that there has been a "breakdown with the four nations," and she does not know "when or how all these barriers were created." 49

In opposition to the divisive barriers between the four bands, Miyo Wahkotowin is advocating an alternate conception of citizenship and community. When a child becomes a student at Miyo Wahkotowin, they are, first and foremost, citizens of the Miyo Wahkotowin community. Their band membership has no relation to how the school treats them. The people interviewed explained that by creating a conception of citizenship in the school, they prepare students to participate as strong, healthy citizens in the community and any other associations that their students might participate in. The people interviewed felt that restorative justice offers Miyo Wahkotowin the ability to teach their students about citizenship and how one can conduct relationships with others.

When I talked about diverse citizenship, the interview participants immediately picked up on the idea because it was a way of talking about citizenship in their school without excluding the idea that the students were also citizens of Maskwacis. The interview participants also talked about moving away from a conception of citizenship where the institutions and practices that regulate conflict are separated from the people actually involved in the conflict.

Wildcat and Mehal also talked about building relationships with the other schools in Maskwacis in order to stop the sense of separation. They mentioned that separation is not a reality anyway (because students move between the schools), so it is important that all of the schools improve together. A school that encounters difficulties on one reserve will impact the other schools when students switch between schools. They stated that it is important to them that all schools in Maskwacis are strong and healthy because it helps Miyo Wahkotowin to be strong and healthy. They told a story about how they interviewed a teacher for a position. Shortly afterward they learned that Nipisihkopahk, which administers education for the Samson Cree Nation, had already signed a contract with the teacher. Because of this, they decided not to interfere with the agreement. They felt that it would have 
been a hostile action that could damage the relationship that Miyo Wahkotowin and Nipisihkopahk are developing.

When asked how they would know if students are adopting the ideas of restorative justice, the participants stated that the students' citizenship skills would spill outside of the school and they would see students leading initiatives in the community where people are coming together to undertake shared action. Restorative justice helps to push forward ideas of community that are vital to organizing the political collectivities of Indigenous peoples in the future. The work being done at Miyo Wahkotowin helps to lay the groundwork for creating strong citizens that will help move us forward on our path to self-determination.

\section{CONCLUSION}

A long road lies ahead for Indigenous peoples to move toward self-determining existences and lives of dignity. Maskwacis exists within an ongoing history of colonialism, and a society that lacks the will to confront the destitute and impoverished conditions of the original peoples of this land. As a community, we suffer from violence, conflict, and a political landscape that fosters a lack of co-operation. The work being done at Miyo Wahkotowin holds transformative potential because it allows the people of Maskwacis to see that another way of conducting relationships is possible. Relating to each other based on the Cree idea of miyo wahkotowin, ${ }^{50}$ and having formations of legitimacy taking root, will allow us to move beyond the current political landscape, which is so destructive to the future of our communities. 
APPENDIX A:

Population Profile of CReE Bands in MASKWACis

\begin{tabular}{|l|r|r|r|r|r|}
\hline & \multicolumn{1}{|c|}{ Total } & \multicolumn{1}{c|}{ On-Reserve } & \multicolumn{1}{c|}{ Off-Reserve } & \multicolumn{1}{c|}{$\begin{array}{c}\text { Other } \\
\text { Reserve }\end{array}$} & Crown Land \\
\hline Ermineskin & 4023 & 2767 & 867 & 287 & 102 \\
\hline Louis Bull & 2020 & 1415 & 364 & 232 & 9 \\
\hline Montana & 939 & 651 & 208 & 79 & 9 \\
\hline Samson & 7353 & 5418 & 1507 & 419 & 121 \\
\hline Total & 14335 & 10248 & 2946 & 1018 & 1 \\
\hline Percentage & & 72 & 21 & 7 & 9 \\
\hline
\end{tabular}

APPENDIX B:

Programming at Miyo WAHKotowin

\begin{tabular}{|c|c|c|}
\hline Program title & Description & Leads into \\
\hline $\begin{array}{l}\text { Regular } \\
\text { Program }\end{array}$ & $\begin{array}{l}\text { Based on the "provincial programs of study, which identify } \\
\text { what students are expected to learn and do in each subject } \\
\text { and grade.” Grades } 1-12\end{array}$ & $\begin{array}{l}100 \text { credit Alberta High } \\
\text { School diploma }\end{array}$ \\
\hline $\begin{array}{l}\text { Adapted } \\
\text { Program }\end{array}$ & $\begin{array}{l}\text { Adjustments to instruction of the provincial program are } \\
\text { made to help address "special education needs of the } \\
\text { student." Grades } 1-9\end{array}$ & $\begin{array}{l}\text { K\&E Program or } \\
\text { Regular Program }\end{array}$ \\
\hline $\begin{array}{l}\text { Modified } \\
\text { Program }\end{array}$ & $\begin{array}{l}\text { "Learning outcomes” significantly different from the } \\
\text { provincial program are put in place in order to "meet } \\
\text { students special education needs.” Grades } 1-9\end{array}$ & $\begin{array}{l}\text { K\&E Program or } \\
\text { Ehpewapahk Program }\end{array}$ \\
\hline $\begin{array}{l}\text { Knowledge \& } \\
\text { Employability } \\
\text { Program (K\&E) }\end{array}$ & $\begin{array}{l}\text { This program is geared toward providing an educational } \\
\text { experience that integrates “essential and employability skills } \\
\text { in an occupational context.” Grades } 10-12\end{array}$ & $\begin{array}{l}80 \text { credit Alberta } \\
\text { Education Certificate of } \\
\text { Completion }\end{array}$ \\
\hline Eagles Program & $\begin{array}{l}\text { Teaches student learning strategies to assist with literacy and } \\
\text { numeracy as well as life and social skills. Grades 1-6. }\end{array}$ & $\begin{array}{l}\text { Junior High Transition } \\
\text { Program or } \\
\text { Adapted/Modified } \\
\text { Program }\end{array}$ \\
\hline $\begin{array}{l}\text { Junior High } \\
\text { Transition } \\
\text { Program }\end{array}$ & $\begin{array}{l}\text { Teaches student learning strategies to assist with literacy and } \\
\text { numeracy as well as life and social skills. Grades 7-9. }\end{array}$ & $\begin{array}{l}\text { Ehpewapahk Program } \\
\text { or K\&E Program }\end{array}$ \\
\hline $\begin{array}{l}\text { Ehpewapahk } \\
\text { Program }\end{array}$ & $\begin{array}{l}\text { Is an alternative high school program. The program has } \\
\text { recently undergone changes and now focuses on character } \\
\text { education, mentorship programs, outdoor education, cultural } \\
\text { activities, numeracy and literacy, helps students to obtain } \\
\text { government identification, and helps bridge students with } \\
\text { short-term certificates. }\end{array}$ & $\begin{array}{l}\text { Alberta Education } \\
\text { Certificate of } \\
\text { Completion or } \\
\text { Ehpewapahk Certificate }\end{array}$ \\
\hline
\end{tabular}




\begin{tabular}{|l|l|l|}
\hline Program title & Description & Leads into \\
\hline EOP Program & $\begin{array}{l}\text { A program for students with severe disabilities that require } \\
\text { one-on-one attention. Instruction takes place in a normal } \\
\text { classroom setting. Grades 1-9. }\end{array}$ & $\begin{array}{l}\text { TSP Program or } \\
\text { Ehpewapahk Program }\end{array}$ \\
\hline TSP Program & $\begin{array}{l}\text { A program for students with severe disabilities that requires } \\
\text { one-on-one attention. Program is geared toward numeracy } \\
\text { and literacy, communication, employability, relationships, } \\
\text { transportation, daily living, and leisure. }\end{array}$ & $\begin{array}{l}\text { Alberta Education } \\
\text { Certificate of } \\
\text { Completion }\end{array}$ \\
\hline
\end{tabular}

